\title{
Shorebird foraging behavior, diet, and abundance vary with harmful algal bloom toxin concentrations in invertebrate prey
}

\author{
Rikk Kvitek, Carrie Bretz* \\ California State University Monterey Bay, 100 Campus Center, Seaside, California 93955, USA
}

\begin{abstract}
We demonstrate how harmful algal bloom (HAB) toxins can change the strength of consumer-prey interactions by altering the foraging behavior of avian predators on rocky and sandy shores. Changes in the foraging behavior and diet of 5 common northern California shorebirds (black oystercatchers, godwits, sanderlings, whimbrels, and willets) correlated with the predicted seasonal variation in paralytic shellfish poisoning toxin (PSPT) concentrations in their 2 major invertebrate prey species, sea mussels Mytilus californianus and sand crabs Emerita analoga, at 2 locations along the California coast. In rocky habitats, when mussel PSPT concentrations exceeded $150 \mu \mathrm{g}$ saxitoxin (STX) eq $100 \mathrm{~g}^{-1}$, oystercatchers increased their consumption of smaller, non-PSPT-accumulating prey (limpets, primarily Lottia spp.), as well as their discard rate of captured mussel tissue. In sandy habitats, when sand crab PSPT concentrations exceeded 150 to $200 \mu \mathrm{g}$ STX eq $100 \mathrm{~g}^{-1}$, shorebird abundance decreased, while their rejection rate of sand crab prey increased. These results confirm the prediction that shorebirds are able to detect and avoid consumption of lethal amounts of PSPT, and that the movement of HAB toxins through the marine food web can alter upper-level trophic interactions.
\end{abstract}

KEY WORDS: Paralytic shellfish poisoning toxins $\cdot$ Harmful algal blooms $\cdot$ Saxitoxin $\cdot$ Shorebirds · Predation $\cdot$ Emerita analoga $\cdot$ Mytilus californianus

\section{INTRODUCTION}

Harmful algal bloom (HAB) incidences are escalating in frequency and distribution worldwide (Culotta 1992, Anderson et al. 2000, Van Dolah 2000, Van Dolah et al. 2001). HABs and their affiliated toxins have a clearly widespread impact on marine ecosystems in general; however, the susceptibility of organisms at individual trophic levels is still being established (Paul 1992a,b, Smayda 1992, 1997, Turner \& Tester 1997, Landsberg 2002, Lefebvre et al. 2002, Shumway 2003). Foraging studies have indicated that prey preference and/or prey avoidance linked to algal toxin presence may have a significant impact on trophic level link- ages, and therefore, key predator-prey relationships (White 1980, Kvitek 1991a,b, 1993, Kvitek et al. 1991, 1993), leading to alterations in ecosystem structure and function.

The hypothesis that HABs play a major role in marine vertebrate/invertebrate predator-prey interactions has been tested for free-ranging sea otters in southeast Alaska (Kvitek \& Bretz 2004). There, sea otters modified their foraging behaviors based on concentrations of paralytic shellfish poisoning toxin (PSPT) in bivalve prey, especially their preferred prey, butter clams Saxidomus giganteus. At sites of intermediate prey toxicity (200 to $500 \mu \mathrm{g}$ saxitoxin [STX] eq $\cdot 100 \mathrm{~g}^{-1}$ ), otters continued to forage on butter clams while dis- 
carding the most toxic body parts. At highly toxic sites (prey toxicity $>500 \mu \mathrm{g} \mathrm{STX} \mathrm{eq} \cdot 100 \mathrm{~g}^{-1}$ ) otters avoided butter clams and other large and abundant but toxic bivalve prey, and consumed smaller and/or less abundant non-toxic species. Butter clams were larger and more abundant in highly toxic feeding areas, supporting the hypothesis that PSP toxicity provides a refuge from sea otter predation.

In controlled feeding experiments with free-ranging gulls, individuals with a history of PSPT exposure avoided tissues from bivalve prey species known to accumulate PSPT, whereas naïve individuals first consumed, but then avoided tissues from PSPT-contaminated bivalves following regurgitation of the consumed tissues (Kvitek 1991b). The impacts of episodic toxic blooms on other pivotal avian predators is poorly reported, and some studies have indicated that naïve groups (Armstrong et al. 1978, Hockney \& Cooper 1980, Shumway et al. 2003) as well as migratory populations are at greatest risk.

Here, we test the general hypothesis that recurrent seasonal increase in prey toxicity due to PSPT producing HABs along the northern California coast influences the foraging behavior, diet, and local abundance of free-ranging avian predators. The objective was to determine if avian predators (1) switch to alternative prey, (2) discard captured preferred prey, and/or (3) abandon a foraging area when PSPT concentrations in their primary prey exceed a threshold value.

\section{MATERIALS AND METHODS}

General approach and study sites. Our approach was to monitor and correlate changes in the foraging behavior of shorebird predators with seasonal changes in $\mathrm{HAB}$ related toxicity of their invertebrate prey in 2 different habitat and community types: (1) rocky shores where black oystercatchers Haematopus bachmani forage on sea mussels Mytilus californianus (hereafter mussels), and (2) exposed sandy beaches where a diverse assemblage of shorebird species forage on abundant sand crabs Emerita analoga (hereafter sand crabs). Both of these prey species are known to accumulate high concentrations of PSPT rapidly and synchronously during $\mathrm{HAB}$ events, and to quickly depurate following each bloom (Bretz et al. 2002). Two study sites (Limantour Beach and Pescadero Beach) separated by $200 \mathrm{~km}$ (Fig. 1) were selected based on the results from $>10 \mathrm{yr}$ of PSPT monitoring by the California Department of Health Services (CDHS) Marine Biotoxin Monitoring and Control Program. CDHS records show a consistent seasonal increase in mussel PSPT concentrations coincident with Alexandrium spp. blooms at both of these sites (Price et al.

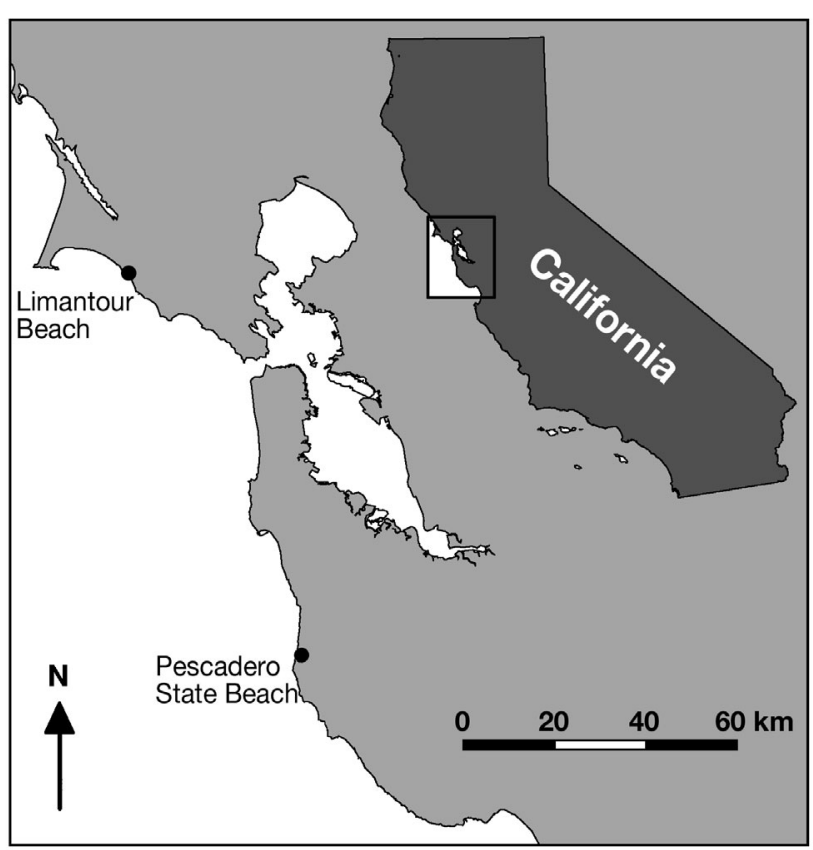

Fig. 1. Map of California showing location of the 2 study sites (Limantour Beach and Pescadero Beach) where shorebird foraging observations and prey paralytic shellfish poisoning toxin (PSPT) monitoring surveys were conducted in rocky and sandy habitats

1991). Rocky and sandy sampling stations located within a few hundred meters of each other were selected at each study site. This pairing of sampling stations enabled comparisons of prey toxicity and predator behavior within different habitat types exposed to similar HAB conditions.

Prey sampling and PSPT analyses. Sand crabs and mussels were collected at each sampling site during the lowest tides of each month from April to September in 1998, and April to November in 1999. Prey species were collected every 2 wk and within $24 \mathrm{~h}$ of each other during the sampling period. Local algal bloom conditions during the study were provided by CDHS staff (G. Langlois pers. comm.). Prey sample tissues were collected, extracted, and analyzed via the following protocols and methods reported in Bretz et al. (2002).

Briefly, sand crabs of varying size classes (approx. 30 to 40 medium-sized individuals) were collected haphazardly from aggregated populations within the beach swash zone, by perturbing the sand with a small shovel and capturing emerging crabs in a $5 \mathrm{~mm}$ mesh net. Whole individuals were rinsed of noticeable particulates (such as sand or algae) using ambient seawater and stored in pre-labeled plastic bags, and frozen at $-70^{\circ} \mathrm{C}$ at the California State University Monterey Bay (CSUMB) facility. Mussel samples ( $\mathrm{n}=25$ to 30 ) were collected and prepared according to CDHS Marine Biotoxin Moni- 
toring and Control Program protocols (Price et al. 1991). Prior to the soft tissue extraction, mussels were rinsed to remove any foreign material adhering to the shell (e.g. limpets or encrusting bryozoans). Extracted tissues of individuals collected at the same site and date were pooled for toxin analyses. Tissue samples were frozen at $-70^{\circ} \mathrm{C}$. These samples were handled and processed according to CDHS Marine Biotoxin Monitoring and Control Program: Field Sampling Protocol for Shellfish, and analyzed for PSPT by CDHS using the standard mouse bioassay.

Shorebird diet and foraging observations. Observations of foraging birds were made on the same days and at the same sites as the prey collections. Oystercatchers were observed in rocky habitats, where they foraged on mussels and limpets (primarily Lottia spp.). A diverse assemblage of shorebird species (godwits, sanderlings, whimbrels, and willets) was observed foraging in sandy beach habitats, from which observations were pooled for all species. Pooling the results for the sandy shore bird assemblage was warranted since all species shared the same foraging zone, where they fed almost exclusively on sand crabs.

Foraging data were collected using a 'continuous focal sample' method (Altmann 1974, Kvitek \& Bretz 2004). Whenever possible, the target bird was followed for $15 \mathrm{~min}$, or until it stopped feeding or moved out of range. Type and duration of the bird's activities were recorded to the nearest second, as well as habitat used, weather, and surf conditions. Major activity categories included searching, prey handling, inactive periods of foraging due to wave interruption, resting, interacting with other birds (especially kleptoparasitism), and outof-view. Prey handling times included the period required for focal individuals to open mussel shells by stabbing, extract and swallow tissues; or for limpets, to pry and dislodge individuals from rocks, move them to a secure, flat space, and scrape tissue from the upturned shell. Foraging tactics on mussels used by all oystercatchers in this study involved stabbing between the valves to open individual prey (Goss-Custard \& Durell 1988, Zwartz et al. 1996). All prey captured during a focal sample were identified and recorded. Rejection and partial consumption of prey was also noted. Hourly census counts of all shorebirds present within a fixed $500 \mathrm{~m}$ length of shore from the survey post at each site were recorded during each sampling date. The peak count for the day was used as that date's shorebird abundance value. The rationale for using peak bird abundance, instead of mean, was to avoid invalid data counts caused by short-term events, such as complete flock disturbance due to dogs or human presence.

Percent diet composition was not determined for the shorebirds in the sandy beach habitats, because the only prey alternatives to sand crabs were mysids and amphipods, which were rarely recorded as present or taken by the birds.

Bird response to varying prey toxicity was highly comparable between study sites allowing us to pool the behavioral data for statistical purposes. Analyses (ANOVA, Student's $t$-test, regression analysis) were performed using Statview for Windows v5.0. Both density and percent data were log transformed prior to analyses. All transformed data were evaluated for and met assumptions for parametric tests.

\section{RESULTS}

\section{Toxicity analyses}

Sand crab and mussel toxicity rose and fell in tight synchrony at all sampling stations (Fig. 2, see Bretz et al. 2002 for a detailed account of PSPT accumulation results). PSPT levels for both species rose above the $80 \mu \mathrm{g}$ STX eq $\cdot 100 \mathrm{~g}^{-1}$ state quarantine level at Limantour and Pescadero during September and October of 1999. Prey toxin concentrations for all other sampling dates during the 2 yr study remained well below the state quarantine level, rarely exceeding the minimum detection limit of the mouse bioassay test ( $~ 38 \mu \mathrm{g}$ STX eq $\cdot 100 \mathrm{~g}^{-1}$ ). According to California State Biotoxin Reports by the CDHS, Alexandrium catenella, the dinoflagellate that produces PSPTs, was present for the first time of the year in northern California in late July 1999. Low levels of PSPT in mussels were detected within this time frame. The distribution and magnitude of PSP toxicity in shellfish increased in August, and reached its peak by late September (September 26 to 28 ) in the region of our sampling sites (Marin county). The abundance of $A$. catenella in coastal waters was linked with the increase in PSPT in sentinel and wild mussel populations (as well as sand crabs) from this area at the time. The A. catenella bloom in the region began to diminish in early October. Both mussel and sand crab toxicities declined rapidly after the measured peak, falling below $80 \mu \mathrm{g}$ the following week.

\section{Shorebird diet and foraging behavior}

Peak shorebird abundance varied inversely with sand crab prey PSPT concentrations in the sandy habitats at Limantour and Pescadero beach study sites during the 13 wk period bracketing the $\mathrm{HAB}$ event $\left(\mathrm{n}=6, \mathrm{p}=0.1591, \mathrm{r}^{2}=0.427\right.$ and $\mathrm{n}=5, \mathrm{p}=0.1432, \mathrm{r}^{2}=$ 0.564, respectively) (Fig. 3). Oystercatcher abundance in the rocky habitats, however, was too low (per survey day) throughout the study to allow statistical compar- 


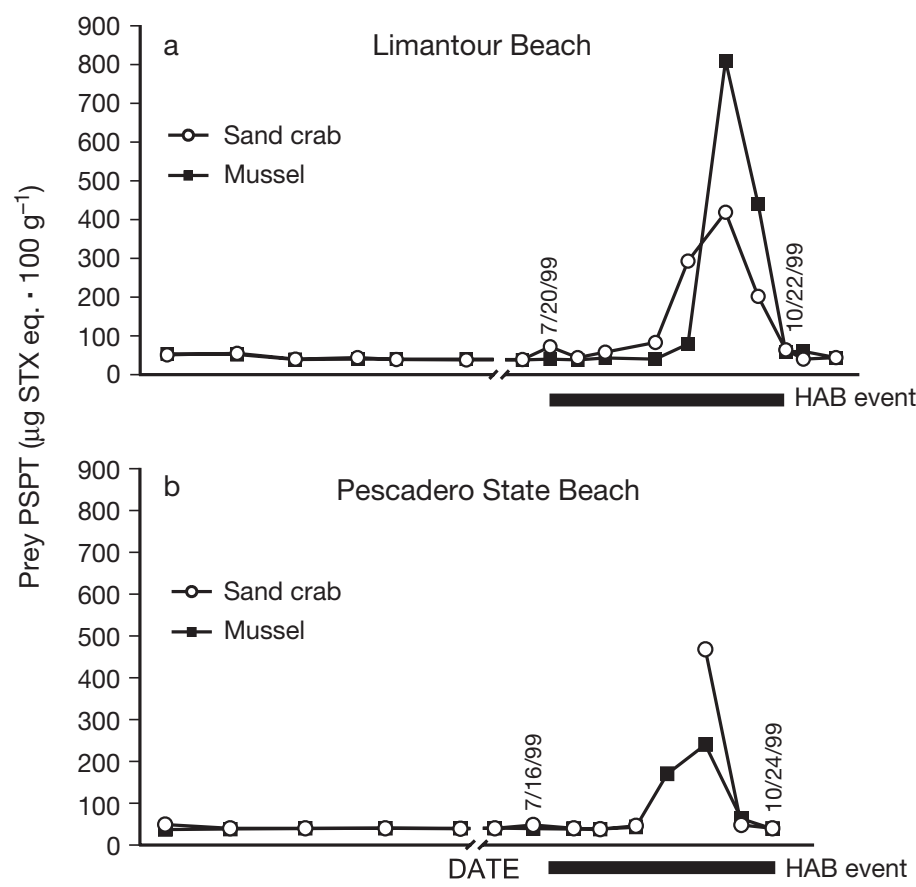

Fig. 2. Emerita analoga and Mytilus californianus. Synchronous rise and fall of paralytic shellfish poisoning toxin (PSPT) concentrations ( $\mu \mathrm{g}$ saxitoxin [STX] eq $\cdot 100 \mathrm{~g}^{-1}$ ) in sand crabs $E$. analoga and sea mussels $M$. californianus at (a) Limantour Beach and (b) Pescadero Beach study sites. Data points represent single values resultant of standard mouse bioassay analyses. Revised from Bretz et al. (2002). Horizontal line represents approximate duration of the local harmful algal bloom (HAB) event based on California Department of Health Services Biotoxin Reports. Dates given as mo/d/yr

isons between toxic and non-toxic prey periods. Oystercatcher diet, however, did change significantly, with limpets replacing mussels as the numerically dominant prey (ANOVA, $\mathrm{p}=0.0008$ ) during periods of high mussel toxicity (>150 $\mu$ g STX eq $\cdot 100 \mathrm{~g}^{-1}$ ) (Fig. 4). Prey switching among shorebirds on sandy beach habitats could not be reliably detected or accurately quantified for 2 reasons. Alternative prey species (mysids and amphipods) were generally not present or, if available, their sizes were too small to allow reliable identification during capture or consumption. The only time these alternative non-sand crab prey appeared to make up a large fraction of the prey captured was at Limantour during the period of high PSPT concentrations in sand crabs.

Rates of prey discard increased significantly at prey PSPT concentrations $>150 \mu \mathrm{g}$ STX eq $\cdot 100 \mathrm{~g}^{-1}$ for oystercatchers in rocky habitats and shorebirds on sandy beaches (Fig. 5) ( $t$-test, $\mathrm{df}=13, t=-8.724, \mathrm{p} \leq$ 0.0001). Oystercatchers rarely discarded any mussel tissues during non-toxic periods, and swallowed their
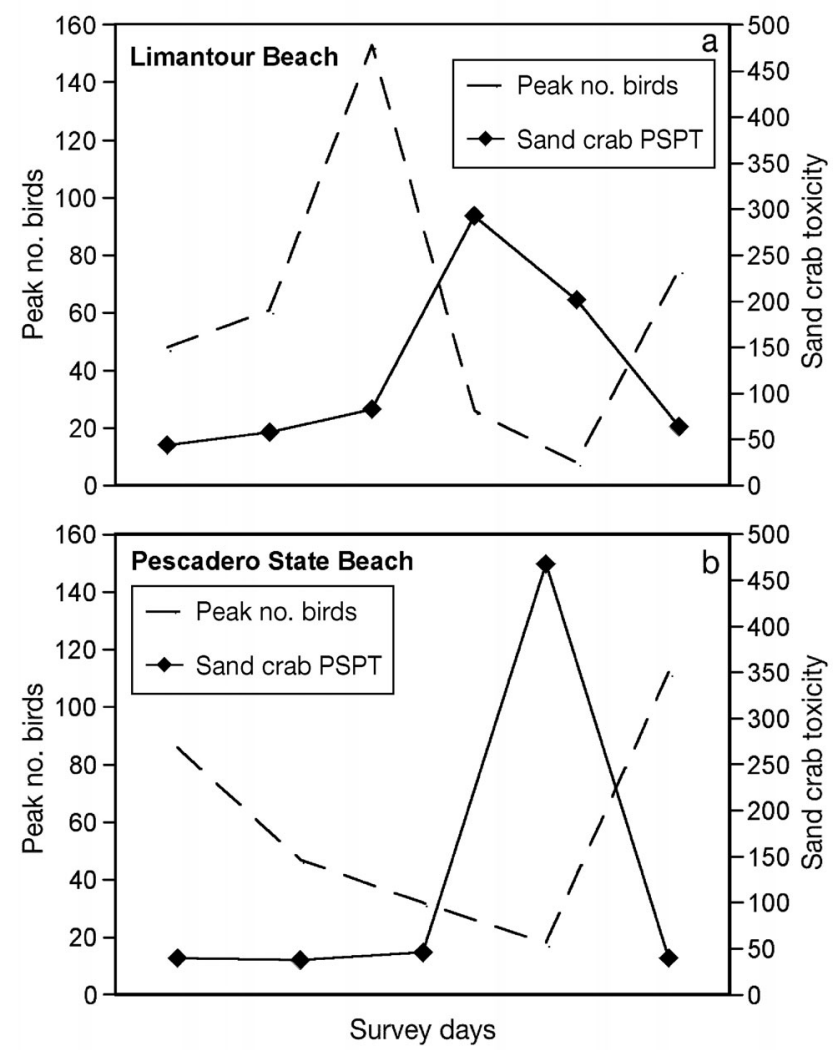

Fig. 3. Emerita analoga. Inverse variation in peak shorebird abundance with sand crab paralytic shellfish poisoning toxin (PSPT) concentrations ( $\mu$ g saxitoxin [STX] eq $\cdot 100 \mathrm{~g}^{-1}$ ) during the 13 wk period bracketing the 1999 harmful algal bloom (HAB) period at the (a) Limantour Beach and (b) Pescadero Beach sandy habitat study sites

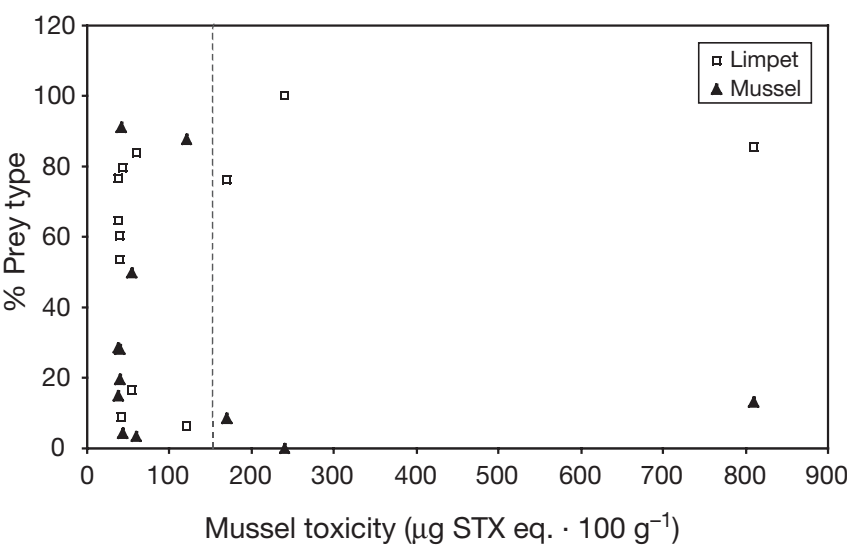

Fig. 4. Haematopus bachmani, Mytilus californianus and Lottia spp. Variation in the relative frequency of $M$. californianus (sea mussels) and Lottia spp. (limpets) in the observed diet of $H$. bachmani (black oystercatcher) versus sea mussel paralytic shellfish poisoning toxin (PSPT) concentration $\left(\mu \mathrm{g}\right.$ saxitoxin [STX] eq $100 \mathrm{~g}^{-1}$ ) at the Limantour Beach and Pescadero Beach rocky habitat study sites. Vertical dashed line marks PSPT concentration at which predator foraging behaviors changed 
prey as quickly as possible upon extraction from the shell. Their behavior changed radically at the higher PSPT concentrations, with much shaking, flinging and dipping of the mussel tissues in water before swallowing, as well as complete abandonment of the extracted tissue. This behavior was never observed when capturing limpet prey.

At the sandy sites, shorebirds did occasionally capture and reject larger sand crabs during periods of low prey toxicity. This behavior, however, was typically associated with individual sand crabs too large to be swallowed easily without dismemberment, or when the sand crabs were very abundant and gravid, and the birds were stripping and consuming only the egg masses carried on the abdomen of females. During the toxic period, rejection of captured sand crabs increased significantly $(t$-test, $\mathrm{df}=10, t=-30.617, \mathrm{p}<0.0001)$ regardless of prey
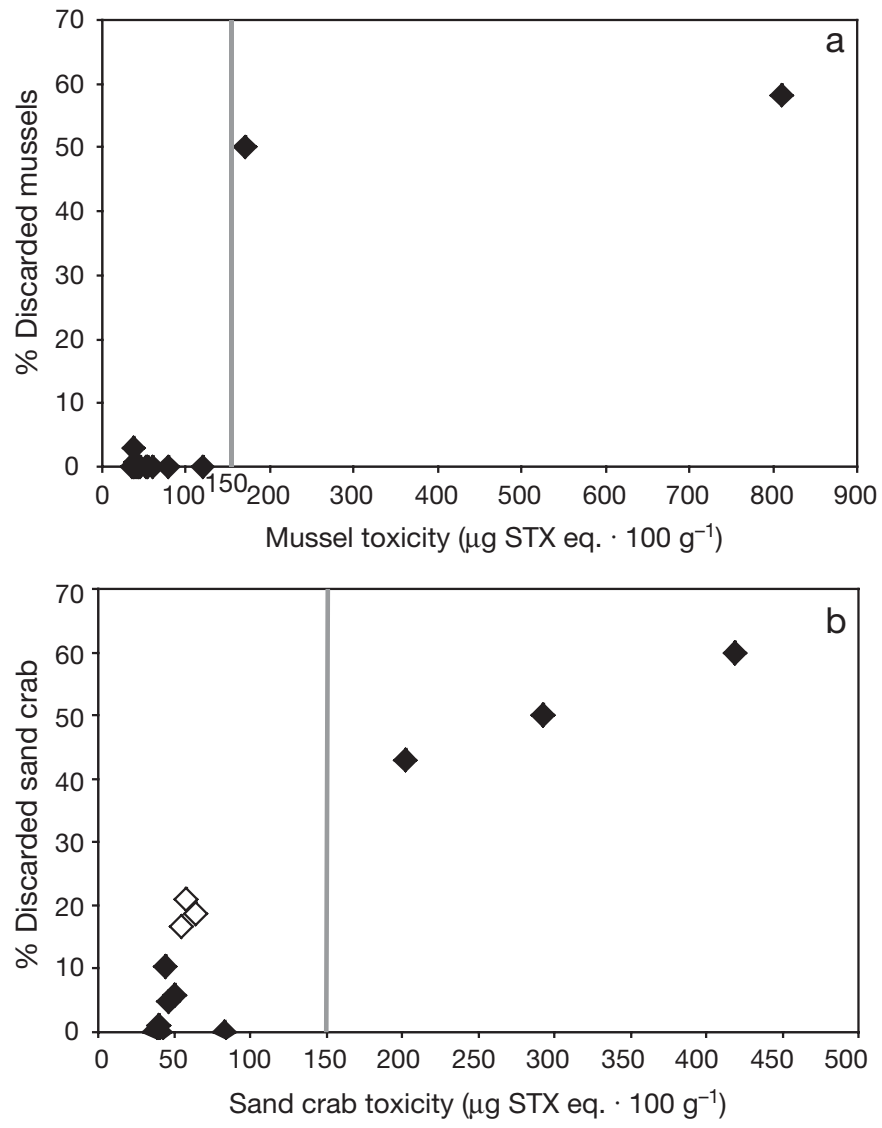

Fig. 5. Mytilus californianus and Emerita analoga. Percentage of observed (a) $M$. californianus and (b) E. analoga captures that were discarded by shorebirds versus prey toxin concentration ( $\mu \mathrm{g}$ saxitoxin [STX] eq $\cdot 100 \mathrm{~g}^{-1}$ ) at the Limantour Beach and Pescadero Beach study sites. Vertical line at $150 \mu \mathrm{g}$ STX eq $\cdot 100 \mathrm{~g}^{-1}$ marks the threshold prey paralytic shellfish poisoning toxin (PSPT) concentration at which predator foraging behaviors changed. $\diamond$ : samples where only egg masses were consumed size, with much shaking and tossing of the individuals before abandonment or infrequent consumption. Rejection of the same discarded prey item was often repeated by successive or kleptoparasitic birds.

\section{DISCUSSION}

These results are consistent with the general hypothesis that shorebirds are able to avoid the consumption of lethal amounts of PSPT by changing their foraging behavior during $\mathrm{HAB}$ periods when these toxins accumulate in their preferred invertebrate prey. The site-abandonment hypothesis is supported by the decline in shorebird numbers observed at both the Limantour and Pescadero sandy beach sites during the HAB period when sand crab PSPT concentrations were $>200 \mu \mathrm{g}$ STX eq $\cdot 100 \mathrm{~g}^{-1}$ (Fig. 3). The consistently low numbers of oystercatchers throughout the study did not allow reliable testing of the abandonment hypothesis at the rocky sites.

The prey switching hypothesis was supported by the diet composition data from both rocky study sites, where oystercatchers shifted from a mussel-dominated diet to limpets during HAB periods when mussel PSPT concentrations were $>150 \mu \mathrm{g}$ STX eq $\cdot 100 \mathrm{~g}^{-1}$ (Fig. 4). Although limpets were not tested for PSPT in this study, they forage by benthic grazing and are highly unlikely to accumulate measurable amounts of PSPT produced by planktonic dinoflagellates. Moreover, PSPTs have not been reported in broad taxonomic surveys of intertidal organisms, including limpets and similar algal foragers/browsers (Quayle 1969, MacDonald 1970, Jonas-Davies \& Liston 1985). Thus, the presence of $\mathrm{HAB}$ toxins in the preferred prey type reversed the relative values of equally accessible principle prey species in the foraging priority of oystercatchers, as scarcity of preferred prey has been shown to do in other optimal foraging studies (Ostfeld 1982).

The prey discard hypothesis was supported by the results from all shorebirds at all sites. Oystercatchers in rocky habitats, and shorebirds on sandy beaches all began rejecting a high percentage of their preferred prey (mussels and sand crabs, respectively) at PSPT concentrations $>150 \mu \mathrm{g}$ STX eq $\cdot 100 \mathrm{~g}^{-1}$ (Fig. 5).

The shift in predator behavior occurred between $125 \mu \mathrm{g}$ STX eq $\cdot 100 \mathrm{~g}^{-1}$, the highest prey PSPT concentration at which there was no observed predator response, and 150 to $200 \mu \mathrm{g}$ STX eq $\cdot 100 \mathrm{~g}^{-1}$, the lowest values at which prey discarding and diet shift were observed. This threshold value is similar to the $200 \mu \mathrm{g}$ STX eq $\cdot 100 \mathrm{~g}^{-1}$ threshold identified for changes in free-ranging sea otter behavior when foraging on bivalve prey containing PSPT (Kvitek \& Bretz 2004), as well as the concentrations in bivalve 
prey that promoted changes in feeding behavior during controlled experiments with free-ranging sea gulls (445 $\mu \mathrm{g}$ STX eq $100 \mathrm{~g}^{-1}$ ) (Kvitek 1991b), captive sea otters (226 $\mu \mathrm{g}$ STX eq $\cdot 100 \mathrm{~g}^{-1}$ ) (Kvitek et al. 1991), and captive fish (135 $\mathrm{\mu g}$ STX eq $\cdot 100 \mathrm{~g}^{-1}$ ) (Kvitek 1991a). The mechanism for toxin detection in higher vertebrates is not known.

\section{CONCLUSIONS}

Although these results suggest that some marine avian predators, more often inshore species, are able to detect and avoid ingestion of lethal concentrations of HAB toxins, this ability may only apply to cases in which the predator's feeding behavior combined with the anatomical distribution of these toxins in their prey enable the predator to 'test' the prey prior to ingestion. Oystercatchers open mollusk prey, exposing all the soft organ tissues to contact with the inside of their mouth and sensory organs in bill tips prior to swallowing (Goss-Custard 1996). Shorebirds in sandy habitats often dismember sand crabs before swallowing, also increasing the likelihood of the prey's soft tissue contacting the inside of the predators mouth. The frequently observed behaviors of shaking, tossing, washing, partially ingesting and finally rejecting prey above the threshold PSPT levels are consistent with the hypothesis that these shorebirds test their prey for toxin concentration prior to swallowing. Our results here confirm the unusual feeding activities noted previously by Falxa (1992). The ability to test prey for HAB toxins is likely not the case for piscivorous sea birds, the marine predators most commonly associated with HAB related mass mortalities (Keyes 1965, Nisbet 1983, Work et al. 1993, Lefebvre et al. 1999, 2001, Scholin et al. 2000, Shumway et al. 2003). These species typically swallow their small fish prey whole, often during feeding frenzies, such that HAB toxins contained in the stomachs of their prey would not be released into the predator's system until digestion took place well after the feeding event. Under these circumstances, it is less likely that HAB toxins would alter feeding behavior or provide a deterrent to predation.

The picture emerging from feeding studies, however, is that many marine predators routinely exposed to PSPT through their invertebrate prey are easily able to detect and avoid poisoning (Kvitek 1991a,b, 1993, Kvitek \& Beitler 1991, Kvitek et al. 1991, 1993, see Shumway et al. 2003). In some cases, this avoidance can result in a refuge from predation for those prey species able to accumulate and retain these toxins (Kvitek \& Bretz 2004). These same types of prey testing and selective discarding behaviors for avoiding or circumventing toxic defenses are seen in avian pre- dators of chemically defended insects (Calvert et al. 1979, Fink \& Brower 1981, Brower \& Calvert 1985, Brower \& Fink 1985).

While we have documented a shift in shorebird predation pressure away from preferred prey species that become toxic with PSPT, the consequence of this change has yet to be measured for the prey populations, either in terms of prey abundance or the timing of important natural history events to coincide with the regular seasonal occurrence of HABs. Furthermore, the documented occurrence of other $\mathrm{HAB}$ related toxins (e.g. domoic acid) in these same invertebrate prey species (Ferdin et al. 2002, Powell et al. 2002) has not been investigated in terms of their impact on predator feeding behavior either in isolation or coupled with PSPT.

Acknowledgements. We thank the following researchers for assistance with foraging observations and prey sampling: K. Thomas, P. Iampietro, M. Ferdin, T. Manouki, S. Kvitek, A. Greenvoss, M. Park, T. Mynster, L. Henkel, P. Byrnes, C. Keiper. Special thanks to G. Langlois at the California Department of Health Services (CDHS) Marine Biotoxin Program for critical information on local harmful algal bloom (HAB) conditions. Also thanks to D. Mills, L. Guthertz and staff at the CDHS Microbial Diseases Laboratory for their expert consultation and mouse bioassay analyses, and J. Barry, V. Trainer, and an anonymous referee for their pre-submission comments. This project was funded through NSF/ ECOHAB grant \#OCE-9726263 to R. Kvitek.

\section{LITERATURE CITED}

Altmann J (1974) Observational study of behavior: sampling methods. Behaviour 49:227-267

Anderson DM, Kaoru Y, White AW (eds) (2000) Estimated annual economic impacts from harmful algal blooms (HABs) in the United States. Woods Hole Oceanographic Institution, Technical report WHOI-2000-11, Woods Hole, MA

Armstrong IH, Coulson JC, Hawkey P, Hudson MJ (1978) Further mass seabird deaths from paralytic shellfish poisoning. Br Birds 71:58-68

Bretz CK, Manouki TJ, Kvitek RG (2002) Emerita analoga (Stimpson) as an indicator species for paralytic shellfish poisoning toxicity along the California Coast. Toxicon 40 : 1189-1196

Brower LP, Calvert WH (1985) Foraging dynamics of bird predators on overwintering monarch butterflies in Mexico. Evolution 39:852-868

Brower LP, Fink LS (1985) A natural toxic defense system: cardenolides in butterflies versus birds. Ann N Y Acad Sci 443:171-188

Calvert W, Hedrick LE, Brower LP (1979) Mortality of the monarch butterfly (Danaus plexippus L): avian predation at 5 overwinter sites in Mexico. Science 204:847-851

Culotta E (1992) Red menace in the world's oceans. Science 257:1476-1477

Falxa GA (1992) Prey choice and habitat use by Black Oystercatchers: interactions between prey quality, habitat availability, and age of bird. PhD dissertation, University of California, Davis, CA 
Ferdin ME, Kvitek RG, Bretz CK, Powell CL, Doucette GJ, Lefebvre KA, Coale S, Silver MW (2002) Emerita analoga (Stimpson) - possible new indicator species for the phycotoxin domoic acid in California coastal waters. Toxicon 40: 1259-1265

Fink LS, Brower LP (1981) Birds can overcome the cardenolide defense of monarch butterflies in Mexico. Nature 291: 67-70

Goss-Custard JD (ed) (1996) The oystercatcher: from individuals to populations. Oxford University Press, New York

Goss-Custard JD, Durell SEA leV Dit (1988) The effect of dominance and feeding method on the intake rate of oystercatchers, Haemoptopus ostralegus, feeding on mussels. J Anim Ecol 57(3):827-844

Hockney PAR, Cooper J (1980) Paralytic shellfish poisoning a controlling factor in Black Oystercatcher populations? Ostrich 51:188-190

Jonas-Davies J, Liston J (1985) The occurrence of PSP toxins in intertidal organisms. In: Anderson DM, White AW, Baden DG (eds) Toxic dinoflagellates. Proceedings of the Third International Conference on Toxic Dinoflagellates. Elsevier Publishers, New York, p 467-472

Keyes MC (1965) Pathology of the northern fur seal. J Am Vet Med Assoc 147:94-109

Kvitek RG (1991a) Paralytic shellfish poisoning toxins sequestered by bivalves as a defense against siphon nipping fish. Mar Biol 111:369-374

Kvitek RG (1991b) Sequestered paralytic shellfish poisoning toxins mediate glaucous-winged gull predation on bivalve prey. Auk 108:381-392

Kvitek RG (1993) Paralytic shellfish toxins as a chemical defense in the butter clam (Saxidomus giganteus). In: Smayda TJ, Shimizu Y (eds) Toxic phytoplankton blooms in the sea. Fifth International Conference Proceedings on Toxic Marine Phytoplankton. Elsevier Science Publishers, Amsterdam, p 407-412

Kvitek RG, Beitler MK (1991) Relative insensitivity of butter clam neurons to saxitoxin: a pre-adaptation for sequestering paralytic shellfish poisoning toxins as a chemical defense. Mar Ecol Prog Ser 69:47-54

Kvitek RG, Bretz CK (2004) Harmful algal bloom toxins protect bivalve populations from sea otter predation. Mar Ecol Prog Ser 271:233-243

Kvitek RG, DeGange AR, Beitler MK (1991) Paralytic shellfish toxins mediate sea otter food preference. Limnol Oceanogr 36:393-404

Kvitek RG, Bowlby CE, Steadler M (1993) The diet and foraging behavior of sea otters in southeast Alaska. Mar Mamm Sci 9:168-181

Landsberg JH (2002) The effects of harmful algal blooms on aquatic organisms. In: Stickney RR (ed) Rev Fish Sci 10: $113-390$

Lefebvre KA, Powell CL, Busman M, Doucette GJ and 7 others (1999) Detection of domoic acid in northern anchovies and California sea lions associated with an unusual mortality event. Nat Toxins 7:85-92

Lefebvre KA, Dovel SL, Silver MW (2001) Tissue distribution and neurotoxic effects of domoic acid in a prominent vector species, the northern anchovy, Engraulis mordax. Mar Biol 138:693-700

Lefebvre KA, Bargu S, Kieckhefer T, Silver MW (2002) From

Editorial responsibility: Otto Kinne (Editor-in-Chief), Oldendorf/Luhe, Germany sanddabs to blue whales: the pervasiveness of domoic acid. Toxicon 40:971-977

MacDonald EM (1970) The occurrence of paralytic shellfish poison in various species of shore animals along the Strait of Juan de Fuca in the State of Washington. Master's thesis, University of Washington, Seattle, WA

Nisbet IC (1983) Paralytic shellfish poisoning: effects on breeding terns. Condor 85:338-345

Ostfeld RS (1982) Foraging strategies and prey switching in the California sea otter. Oecologia 53:170-178

Paul VJ (1992a) Ecological roles of marine natural products. Comstock Publishing Associates, Ithaca, NY

Paul VJ (1992b) Chemical defenses of benthic marine invertebrates. In: Paul VJ (ed) Ecological roles of marine natural products. Comstock Publishing Associates, Ithaca, NY, p 164-188

Powell CL, Ferdin ME, Busman M, Kvitek RG, Doucette GJ (2002) Development of a protocol for determination of domoic acid in the sand crab (Emerita analoga): a possible new indicator species. Toxicon 40:485-492

Price DW, Kizer KW, Hansgen KH (1991) California's Paralytic Shellfish Poisoning Prevention Program, 1927-89. J Shellfish Res 10:119-145

Quayle DB (1969) Paralytic shellfish poisoning in British Columbia. Fisheries Research Board of Canada Bulletin, Ottawa

Scholin CA, Gulland F, Doucette GJ, Benson S and 22 others (2000) Mortality of sea lions along the central California coast linked to toxic diatom bloom. Nature 403:80-84

Shumway SE, Allen SM, Boersma PD (2003) Marine birds and harmful algal blooms: sporatic victims or under-reported events? Harmful Algae 2:1-17

Smayda T (1992) Global epidemic of noxious phytoplankton blooms and food chain consequences in large ecosystems. In: Alexander Sherman KLM, Gold BD (eds) Food chains, yields, models, and management of large ecosystems. Westview Press, Boulder, CO, p 275-307

Smayda T (1997) Bloom dynamics: physiology, behaviour, trophic effects. Limnol Oceanogr 42:1132_1136

Turner JT, Tester PA (1997) Toxic marine phytoplankton, zooplankton grazers, and pelagic food webs. Limnol Oceanogr 42:1203-1214

Van Dolah FM (2000) Marine algal toxins: origins, health effects, and their increased occurrence. Environ Health Perspect 108(Suppl 1):133-141

Van Dolah FM, Roelke D, Greene RM (2001) Health and ecological impacts of harmful algal blooms: risk assessment needs. Human Ecol Risk Assess 7(5):1329-1345

White AW (1980) Recurrence of kills of Atlantic herring (Clupea harengus harengus) caused by dinoflagellate toxins transferred through herbivorous zooplankton. Can J Fish Aquat Sci 37:2262-2265

Work TM, Barr B, Beale AM, Fritz L, Quilliam MA, Wright JLC (1993) Epidemiology of domoic acid poisoning in brown pelicans (Pelecanus occidentalis) and Brant's cormorants (Phalacrocorax penicillatus) in California. J Zool Wildl Med 24:54-62

Zwarts L, Cayford JT, Hulscher JB, Kersten M, Meire PM, Triplet P (1996) Prey size selection and intake rate. In: Goss-Custard (ed) The oystercatcher. Oxford University Press, New York, p 30-55

Submitted: July 20, 2004; Accepted: February 8, 2005

Proofs received from author(s): May 10, 2005 